\title{
Paying the Rent: languaging particularity and novelty
}

\author{
Pagando o Aluguel: particularidade e \\ originalidade no uso da linguagem
}

Charles Bazerman

Gevirtz Graduate School of Education

University of California, Santa Barbara

\begin{abstract}
Issues of plagiarism and originality have been revivified by the internet in two distinct ways. First, the internet has provided new resources for both school learning and school cheating - raising values of individual responsibility, academic integrity and institutional policing. Second, the internet has heightened the tension between intellectual property and the cultural commons - raising values of economic reward and ownership versus those of cultural heritage, communal creativity, and critical comment. A Bakhtinian way of sorting through these two important sets of issues, without conflating the distinct sets of concerns, is to recognize how deeply we are always embedded in the language of others, using and responding to utterances that proceeded ours, while also recognizing the supplement of originality, freshness, or situational specificity expected in particular tasks. When we analyze academic and other situations from this perspective we find that the expected reliance on the cultural commons and the expected supplement varies from task to task, and a procedure which is considered cheating or a failure of originality in one situation is expected and appropriate in another. In educational settings we would do well to identify with greater specificity how students should use the cultural commons in each task and the specific forms of fresh or novel work we also expect them to accomplish. We should then calibrate our identification of plagiaristic cheating in relation to the specific expected originality appropriate to the task.
\end{abstract}

KEYWORDS: Plagiarism; originality; school learning; school cheating.

RESUMO: Problemas de plágio e originalidade têm sido reavivados pela internet de duas formas distintas. Primeiro, a internet tem proporcionado novos recursos tanto no âmbito da aprendizagem quanto no âmbito da fraude escolar - trazendo à tona valores de responsabilidade individual, de integridade acadêmica e de políticas institucionais. Segundo, a internet tem aumentado a tensão entre a propriedade intelectual e cultural do que é comum - elevando os valores da

*bazerman@education.ucsb.edu 
recompensa econômica e da propriedade contra os valores que se referem ao patrimônio cultural, à criatividade coletiva e ao comentário crítico. Uma maneira bakhtiniana de distinguir esses dois conjuntos importantes de questōes, sem misturar seus interesses particulares, é o de reconhecer o quanto estamos incorporados na linguagem dos outros, usando e respondendo a ditos que procederam aos nossos, reconhecendo também que adicionamos a isso algum detalhe de originalidade, novidade, assim como a especificidade situacional esperada de tarefas particulares. Quando analisamos situaçôes acadêmicas e outras particulares a partir dessa perspectiva, nós achamos que a dependência prevista do contexto cultural comum (de domínio público) e do detalhe de originalidade ou novidade a ser adicionado varia de tarefa para tarefa, e um procedimento que é considerado como uma trapaça ou como desprovido de originalidade em uma dada situação é o que é esperado de outra, ou seja, é considerado adequado a outra situação. Em contextos educacionais, faríamos bem em identificar com mais especificidade como os alunos deveriam usar a cultura comum em cada tarefa dada, bem como as formas específicas de inovação ou originalidade que também esperamos que eles realizem em suas tarefas. Devemos então ajustar o que identificamos como plágio ou fraude escolar em relação às nossas expectativas quanto ao que esperamos de originalidade em uma tarefa.

PALAVRAS-CHAVE: Plágio; originalidade; aprendizagem escolar; fraude (cola) na escola.

The ancient topics of plagiarism, imitation, and originality have gained new prominence in the age of the internet in relation to two issues that evoke different spectra of values. First, the internet has provided new tools, new fears, and new urgency to questions of school cheating — raising values of individual responsibility, academic integrity and institutional policing. Second, the internet has heightened the tension between intellectual property and the cultural commons - raising values of economic reward and ownership versus those of cultural heritage, communal creativity, and critical comment. The first pits integrity versus individual expediency that is destructive to the institutions of education. The second weighs the nature of property and how it might be balanced against other social values, including each generation's access to the accomplishments of the previous. Both of these discussions are important, but it is hard to speak of them in the same space without conflating distinct sets of concerns. Yet in sorting through these issues we will also gain clarity on other related concerns that test the boundaries of individual and communal creativity, such as the role of schools in enculturating students into received knowledge and practice versus the role of schools in fostering individual judgment and accomplishment.

The words we speak and write grow out of the words of others. Our use of each other's words makes language possible and our response to the 
words of others motivates us to speak. This realization about the intertwining of our words with the words of others complicates the certainty of moral judgment many attach to plagiarism. Using each other's words is no sin, but it does go back to the origin; it is the seed of human knowledge, and it is the means of our originality and intellectual differentiation. Schools, in particular, intentionally surround children with the words and knowledge produced by their culture so that each new generation can draw on these wells. Yet we also know there are criminals, people who abuse others' words for narrow selfinterest, and we also know that some students cheat by relying too directly on the words of others.

The paradoxes of originality arise because we use the common stock of words, topoi, figures, organization, phrases, and all the other tricks of language to fit the moment and situation. As Bakhtin says, we populate the language of others with our intentions (p. 294). The words may be familiar, but the intention is ours at that moment in that situation. Children in and out of school are constantly expected to speak and write to reveal what they have learned from reading others, what they understand as relevant to the questions being asked of them in the moment. Further, in some situations our utterances are expected to have the ring of novelty or special situational appropriacy. Depending on the question, a student may be expected to draw fresh implications, applications, or conclusions, but wandering too far into the student's own thoughts risks falling into error or off the topic. At the right moments the appropriate appearance of novelty may grant the benefits of recognition, privilege, or future authority if the words succeed, but if the words are found wanting, intentions and acts may be incomplete and subject to failure, leaving a blemish on future reputation and authority. So, if we rent words, certain tasks require us to pay the rent by particular work of our own. But this is not a single kind of work - different genres, activity systems, and situations call for different kinds of work. So while there may not be an original sin here, there are many potential local failures.

Before we analyze these moments of failure to do specific forms of work, let me reframe the problematic of originality. Every child born since the start of language grows up in a complex built symbolic environmentbuilt and maintained by predecessors and compeers. Without the constant animation and reanimation of that symbolic environment and without each child's learning to participate in it, it would collapse into a silence that separates people. Schools serve to familiarize students with these symbolic riches, to 
engage students in the meanings of this heritage, and to enable them to act wisely using these resources in the fresh circumstances of their lives in an evolving society. In this symbolic environment, children learn to do the repetitive, the expected, and the unexpected. Further, each child born today, 5000 years into the literacy experiment, 1000 years into the print experiment, 150 years into the electric communication experiment, and a decade into the world-wide-web experiment lives in an increasingly dense symbolic world, resonant with messages from long ago and far away and messages that encompass the globe in an instant. Yet this inscribed symbolic world must be constantly animated in use to be more than scratches in clay or electrons entropically sinking into disorder.

This environment is ever more complex and people find themselves in increasingly novel positions in a proliferating landscape. But this world is not inchoate-it is organized through activity systems and genres that mediate particular interactions and relations, and that form chronotopic expectations for information, location of knowledge spaces, and unfolding of symbolic events. In this symbolic environment we learn by imitation and appropriation, yet we always act from the origin point of ourselves and our intentions to mark our presence, interests and action - no matter how forthcoming, clever, strategic, coded, deferential, defensive, reticent, submerged, or hidden we may inscribe ourselves. Even when we only respond to a request for our names, we respond from the origin, appropriately. And when we account the events of our lives or what we have witnessed, we respond from our origins with particularity and novelty. In each case we create a unique presence in the symbolic world - time and place stamped with local content. Our comments are anchored to the unique moment and within a unique co-text and intertext by the pervasive linguistic features of indexicality.

But we do not attribute originality to each of our acts. In many situations attribution of "originality" is not desired or prized. I study tai chi and sing in a chorus. In both activities, individuals work hard-physically, technically, cognitively and emotionally — to inhabit and reanimate a deeply familiar practice. We do not want ill-formed notes or movements, but rather a performance filled with intention and meaning that reinhabits and reanimates the tradition as we best can understand it — guided by the local master or conductor whom we trust as having a connection with the originary conception. In the same vein, some people have a talent for the heart-felt fulfillment of the phatic rituals of daily life, and some people are inspired 
clerks. In much school learning we are looking for just that meaningful inhabitation of the formulas - at least until one moves into the upper reaches of scholarship. It is not only arithmetic, calculus, classical mechanics, or even economics that calls for inspired performance of the familiar. In literary studies ability to recount the content and articulate a meaningful appreciation of the creative work precedes fresh analysis, and in history being able to retell the received tales with understanding and engagement precedes fresh archival work.

Only some specific situations in school and life seem to call for novel work, which would earn the attribution of originality and bring to the creator specific and appropriate recognitions, credit, and rewards. It is failure to meet the situational expectation for originality that would open up an attribution of plagiarism, lack of talent, or other failing. We sometimes take the laws surrounding intellectual property as prototypically defining originality, for the law of intellectual property hangs on the idea of innovation. And the definition and application of originality is regularly argued in court. But copyright and patents also exhibit the odd particularity of what we consider originality. First, only cases that are in fact economically consequential are litigated or litigatable, and in a sense worthy of determining originality. If there is no substantial financial interest, courts will not hear cases and there will be no judgment of originality. Further, the case will likely be civil, not criminal, and penalties will likely be financial.

The patent or copyright grants a temporary license to monopoly economic benefit for a particular kind of novel work, to encourage production of these novelties, which are considered a benefit to the nation and public. The nature of novelty has been contested since the beginning of intellectual property law. In patent law, one general formulation has been that the innovation would not be obvious to one versed in the practice; this is a cognitive evaluation of an idealized audience, and not an issue of wording, or formulation. Originality in copyright law, however, is a matter of copying wording or formulation. So in copyright one is free to use the ideas of the other as long as one can reformulate those ideas in ways that are sufficiently distinct. One can even then copyright the new formulation of the borrowed idea.

If you have ever written textbooks you likely will have confronted oddities of copyright. Textbooks in a subject often share a high degree of similarity in structure, topics, content, and analysis, in part because they must compete head to head to serve similarly structured courses, and in part because there is the common practice of studying one's competition. I know of few 
cases of plagiarism being litigated between producers of closely similar textbooks, even if a leading book is widely copied in form, content, or approach. On the other hand, legal departments of publishers watch like hawks any quoted material you use, even though it is clear that the inclusion of this material will not harm the economic value of the original publication, but will likely increase its visibility and value. Thus you fear litigation not from the competitors you copy, but from third parties you are publicizing.

The textbook market reveals also another face of originality that has little to with intellectual property law. Textbooks may be valued because they have exactly what is expected in the most accessible way that incorporates all the innovations of all the other books. Books that are too original may be less valued. While some books may present a novelty in pedagogy or presentation that is highly prized and emulated, it may be the books that copy the innovation putting them in a more conventional form that are best valued in the market. Nonetheless, all of these books are equally copyrightable.

In books directed toward entertainment, however, there is usually a more consistent desire for originality, because just the right amount of novelty of the right kind gets our attention. On the other hand too much novelty of the wrong kind makes the work unrecognizable, meaningless, unengaging, and unentertaining. We know this from cognitive experiments with infants where variation of a rhythm or light pattern can energize attention, and repetition dull it; other stimuli outside attention or ability to interpret, however, go unnoticed. But again what kind of work this novelty consists of may vary from book to book. A detective story may gain from having fresh characters and fresh locales, but must deliver intriguing but unresolved clues. In pirate movies of mid-century a major site for innovation and amusement is in the ingenious daring of swinging from masts.

For literature considered more serious, an attribution of derivativeness, though not litigatable, indicates a major failing, but in other cases other influences serve to mark the genre, identify the homage, provide a field against which new meanings and experiences are created. It takes detailed analysis of each case to locate the combination of sources and influences that underlay the text, that reformulate uniquely in combination and local context, and that provide sites for specific surpluses of creation. Which of these combinations and excesses in which context, drawing on which resources the writer brings, provide for a depth of expression, observation, imagination, structure, or thought to be considered original? Which will be seen as fakery, ineptly 
parading in borrowed costume? It is the work of literary criticism to parse the virtues, sources, and inventive work of texts valued for their uniqueness. The tropes and measures of literary originality are quite distinct from those of the intellectual property courts.

In news, novelty comes not from the freshness of the wording or structuring which are so routine as to be churned out against deadline, but in the happenings reported which are to be collected and transcribed through witnessing in real time and going to the right sources. Failures and fakery here have to do with not being in the right place, not going to the right source, making up material (being too original!) not grounded in fact gathering. In the extreme case, stock reports must be original every day, but the elements are absolutely repetitive, in form, and in source-which are signs of authority and accuracy.

In science, plagiary and fakery are rarely of immediate economic value, but steal fame (which might have secondary rewards for tenure, promotion, and reputation) or mislead colleagues, wasting their time on unauthenticated or faked results. There the work of originality depends on both intertextual savvy and material practice — on both theoretical and empirical work. All these forms of work rely on learning from the writings of colleagues, which is then re-represented as part of identifying one's contribution.

We could continue the examination in every other sphere where visible word borrowing or allegation of inauthenticity of words is attributed as a failing, and in each case we will see a somewhat different configuration. Politics is particularly interesting in that political speeches are highly patterned and familiar in content and phrasing, and politicians themselves are evaluated not for originality so much as leadership, trustworthiness, representation of group values and interests - and other such communal phenomena. But every once in a while a politician gets in trouble for borrowed words - though not for purchased ones (from their hired speechwriters).

But to academics and educators the site most important to sort out, and the one currently most conflated ideologically with other settings, is schooling. In schooling the kinds of novelty and work added we look for are quite distinct from what concerns us in other domains, and we make serious pedagogical mistakes by not recognizing the particularity of our educational interests in work added by students. No serious money is involved, nor fame and promotion, nor amusement, nor the production of new documents that extend the human experience, nor the production of reliable news. We are, 
rather, concerned with student learning and development which we believe requires students to perform certain kinds of work while producing texts, by which we then evaluate student learning.

Student learning and growth is not necessarily congruent with originality. There are many moments from primary through undergraduate education where it is appropriate for students to repeat words from their books, lectures, and class discussion, even without attribution. Many classrooms live under the umbrella of a single authoritative voice embodied in an alliance of textbook and teacher. Students are expected to repeat mantras from their mathematics, physics, biology and grammar textbooks at the appropriate moments, and apply them in problem procedures that are so familiar and expected that the teachers are given answer keys. There is no need for citation, because everyone knows the textbook defines the universe of discourse. Students who remember from the textbook without citation are praised. Those who use the intermediary of a classmate in the exam room are punished. However, a study session with the same classmate and the same textbook the night before would help both do well on the exam.

This does not mean that there is no intellectual work in learning calculus or sentence subordination or chemical analysis-but only that the work the students need to accomplish is authoritatively guided and the results known. Students have to think and work hard to get to the right place, but that place will have no surprises for the more knowledgeable instructor.

Until students reach more advanced levels of schooling, originality if it is desired, is a specialized domestic creature. Student products, if surprising, are likely to be so because of what we know about the student, rather than because no similar utterance has ever come from the mouth or pen of a student or scholar. When the task is summary (and consider that some student summaries can be surprisingly good), the task is of selection, arrangement, coherence, and transition-not of coming up with fresh wording. It is expected that students will use some wording from the original—with no need to scatter quotation marks throughout. Only an overall attribution to the text summarized is sufficient. Where multiple sources are drawn on, or students are asked to take on commentary roles with respect to texts, then citations may need to be more explicit and wording of the sources needs to be marked. Even then shared resources that pervade the classroom may not need specific citation in the resulting essays. The need for explicitness of citation increases as students reach beyond the texts that are common ground in the classroom. In the case 
where outside materials are welcome or even expected, it could be that simply the hunting out and selection of appropriate resources may be the extent of the novel intellectual work appropriate to the situation. Or complex tasks of analysis, evaluation, synthesis, or application may constitute the desired intellectual work.

Plagiarism, failure, success, or exceptional success, or going off the tracks is finely calibrated to specific pedagogic goals. Insofar as we can articulate the particular kind of work students are expected to do in the situation, the better we can direct them, give support, and evaluate their products. In some cases, the teacher would prefer that students would remain within the bounded discursive space of the classroom to encourage students to be responsible for all the analytic, evaluative or discussion discourse, all the supplement to the required reading. In such cases students reaching for novel sources (whether overtly or covertly) in a sense poison the pristine field for student production of original utterances - even if those "original" utterances might be quite pedestrian in any larger intellectual world.

In different subject matters and different kinds of inquiry students may be asked to bring in unique material and think fresh thoughts in relation to them. To think about literature from even the earliest age, children may be asked for personal experiences and observations even though fresh statements about critical theory may be many years away. In social studies, students' personal experiences and observations about the world around them come in and out of focus at different levels, although social science inquiry may wait until the undergraduate or even graduate years.

We want to define activities and exercises that allow students to develop, practice, and display specific forms of intellectual work. And we also want to give them the means to draw on the extensive knowledge resources available in the library and internet. If their work does not create sufficient distance and novelty from the sources they are working with, however, there will be failure - which might be interpreted as lack of skill or fraud in any particular case. If there is substitution of work by other people-knowingly or unknowingly_-for the work we wish students to accomplish, then they have avoided the work we want them to engage in. The tension between students' drawing on more extensive resources at the same time as they face increasing demands for their own synthesis, analysis, evaluation and argument creates challenges for student writing. If they cannot resolve this tension at their level of skill and within the time and energy they feel they can allot to 
the task, they may elect a short cut. Some students may be so alienated, cynical, or self-indulgent that they set the bar low on the effort they are willing to devote, but most students I know want to learn and will do the work, if they can find a way to do it legitimately. Most acts of conscious plagiarism I have seen are last minute desperation moves. When the instructor sets the right tasks, identifies difficulties ahead of time, and provides guidance and support, students can usually learn to be original in the ways expected of them.

Ultimately we hope students develop independent voices in the public or professional discourses that become important to them. But even this ultimate goal is no unified one. A public servant, a business executive, or a lawyer each has a different relation to different received bodies of discourse and needs to transform them in different ways to complete their tasks and realize their potentials for action. Among academics, a philosopher stands in a different relation to the previous utterances of the field and will be rewarded for producing different kinds of documents than a chemist or an anthropologist. Just consider the kind of reading each will have to do, the kinds of inquiry practice and data gathering each will need to perform, and the pattern of citations each will have to gather in order to create an original publishable article. Learning how to do these things is learning how to be, think, and act like a public servant, an executive, a lawyer, a philosopher, a chemist, or Anthropologist.

So there are many points of origin for our statements, and only some of them are in any sense personal-many of the originary points are deeply communal. Locating and acting on the right originary sources for any task is important so that we know what we are doing and do it well, but only in a subset of those tasks do we seek the attribution of originality. And in those cases, originality has to do with specific kinds of work to be performed. Originality is not a general characteristic of a personality, nor is it a general faculty to be uncovered within individuals. It is in each case a specific accomplishment, and its failure has specific local implications.

I end with a paradox: the more one attunes to communal existence and the resources communally developed, the more focus and resources one can bring to a task so as not to view the task in a conventional way and not to be limited to the most conventional tools. Deeply immersed in the situation and attuned to a wide selection of the potential resources developed over human history, one can perform work that appears more original across more circumstances, finding fresh possibilities within the particulars of 
circumstances than the person who prizes difference and stands apart. It is this paradox that makes plagiarism paranoia so harmful. Plagiarism paranoia puts barriers between us (teachers, writers, students) and as much of the human experience and accomplishment as our path through life allows. Only by drawing deeply from the collective resources can we add most fully to them and pay our share of the rent.

\section{Reference}

BAKHTIN, Mikhail M. The Dialogic Imagination. Austin: University of Texas Press, 1982.

Recebido em janeiro de 2010. Aprovado em fevereiro de 2010.

RBLA, Belo Horizonte, v. 10, n. 2, p. 459-469, 2010 